\title{
Decline in a Tilletia indica Teliospore Population in a Naturally Infested Arizona (USA) Wheat Field
}

\author{
Gary L. Peterson ${ }^{1 *}$, Kathleen L. Kosta ${ }^{2}$ \\ ${ }^{1}$ USDA ARS Foreign Disease-Weed Science Research Unit, Fort Detrick, USA \\ ${ }^{2}$ California Department of Food and Agriculture, Sacramento, USA \\ Email: *gary.peterson@ars.usda.gov
}

How to cite this paper: Peterson, G.L. and Kosta, K.L. (2017) Decline in a Tilletia indica Teliospore Population in a Naturally Infested Arizona (USA) Wheat Field. American Journal of Plant Sciences, 8, 2622-2634. https://doi.org/10.4236/ajps.2017.811177

Received: August 17, 2017

Accepted: October 9, 2017

Published: October 12, 2017

Copyright ( $) 2017$ by authors and Scientific Research Publishing Inc. This work is licensed under the Creative Commons Attribution International License (CC BY 4.0).

http://creativecommons.org/licenses/by/4.0/

\section{c) (i) Open Access}

\begin{abstract}
Following a 2004-outbreak of Karnal bunt in an Arizona wheat field where infection had not been detected in recent years, the population and viability of Tilletia indica teliospores in surface and subsurface layers of soil were monitored over a four-year period. The field was seeded with two parallel $1.8 \mathrm{~m} \times$ $190 \mathrm{~m}$ strips of wheat, $11 \mathrm{~m}$ apart and the remainder planted in non-host barley. Thirty-eight $1.22 \mathrm{~m}^{2}$ wheat plots were harvested and seed examined for infection. Several times throughout each season soil samples were taken from each of 25 points throughout the field. Teliospores extracted from subsamples of each soil sample were examined to estimate the number of teliospores per gram soil and germination percentage. The average (SD) infection observed for each of the four consecutive seasons was 7.05 (4.6), 2.89 (5.5), 0, and $0.004 \%(0)$. The average number of teliospores recovered per gram of soil during the first sampling was 36 and 39 for the $0.5 \mathrm{~cm}$ deep (surface) and 5.5 $\mathrm{cm}$ deep (subsurface), respectively, with an average teliospore germination of $29 \%$. By the last season, the average numbers of teliospores recovered were 5 and 2.5 per gram of soil, respectively, with an average germination of $1.0 \%$.
\end{abstract}

\section{Keywords}

Karnal Bunt, Soil Survival, Teliospore Recovery

\section{Introduction}

Karnal bunt of wheat, caused by the fungus Tilletia indica Mitra, was first detected in the United States in wheat fields in the state of Arizona in 1996. It was subsequently found in Riverside County, CA and in isolated areas of Central and 
Northern Texas [1] [2]. This soilborne, non-systemic pathogen infects wheat heads at flowering via secondary sporidia originating from basidiospores produced by germinating teliospores on the soil surface [1]. The geographic distribution of the disease has been reported primarily in arid and semi-arid environments on fall-sown wheat varieties grown on irrigated land. Prior to its incursion into the U.S., it was reported in Mexico, Afghanistan, India, Pakistan, Iran, Iraq, Nepal [3], Brazil [4], and South Africa [5]. Agronomic losses attributed to the disease are minimal; however, because of the quarantine status of the pathogen, the potential economic losses due to trade restrictions and subsequent disease management costs could be significant [1] [6] [7] [8] [9].

In the US, wheat determined to be positive for $T$. indica teliospores is not permitted to be used for seed or grain but may be converted to animal feed via steam flaking (to kill the pathogen) or it may be buried on the growers property or public landfill. The fields in which the wheat was grown are placed under quarantine regulation as well as any wheat field within a 3-mile radius. A field can be deregulated if it has been permanently removed from crop production, or tilled once annually for a total of 5 years, and after tilling planted with a cultivated non-host crop or planted with a host crop that tests negative, through the absence of bunted kernels [10].

In support of this deregulation policy, a number of controlled studies have been referenced regarding the effects of temperature and soil moisture on the survival of teliospores in soil over time. Most showed a significant decline in viable spores during the first year but a portion persisting for more than several years. In those studies, teliospores were added to soil in the laboratory and transferred to $20 \mu \mathrm{m}$-pore size mesh polypropylene bags or pots that were either buried directly in the quarantined field [11] [12] or placed in a secondary containment container that was then buried in non- $T$. indica infested fields [13] [14] [15]. The latter studies also examined the effect of soil type on teliospore survival.

In 2004, heavy infection of wheat was detected in a Maricopa, AZ $\left(\mathrm{N} 32^{\circ} 59.1441, \mathrm{~W} 112^{\circ} 2.97966\right)$ research field planted to spring wheat and barley in the fall of 2003. The field had previously been planted in wheat and monitored for Karnal bunt since 2002, and currently under regulation due to detection of bunted kernels three years earlier. This presented an opportunity to compare results obtained in the four previous controlled soil studies with those of a natural field population of $T$. indica teliospores. A study was initiated to monitor the teliospore population in the soil over the next four seasons.

\section{Materials and Methods}

\subsection{Experimental Field}

The two-hectare experimental field was established under Federal and State permit to pursue a number of research studies involving viability teliospores. The soil type was Sasco clay loam (pH 7.4, 28\% sand, $40 \%$ silt, $32 \%$ clay, $2 \%$ 
organic matter). In November, "Cavalier" spring wheat was seeded in two parallel strips, $1.8 \mathrm{~m}$ wide, $11 \mathrm{~m}$ apart, $190 \mathrm{~m}$ long, $11 \mathrm{~m}$ from the road and $35 \mathrm{~m}$ from the adjacent field. Strips were planted with a commercial planter at a seeding rate of $3.3 \mathrm{~g}$ per meter of furrow, approximately $2.5 \mathrm{~cm}$ deep. Areas not planted in wheat were seeded with a non-host VNS spring barley in an attempt to limit the edge effect during the study. After planting, fields were initially irrigated at a rate of approximately $15 \mathrm{~cm}$ of water per $\mathrm{m}^{2}$. Subsequent fertilization and irrigation followed local best management practices used on the farm.

Beginning in November 2002, a total of 32 plots for disease monitoring were established within the two strips of wheat, each $1.22 \mathrm{~m}^{2}, 9 \mathrm{~m}$ apart and surrounded on four sides by a $12.7 \mathrm{~mm}$ plywood fence $33 \mathrm{~cm}$ high, trenched into the soil $5 \mathrm{~cm}$ deep and backfilled along the edges. Boxes were anchored with wooden stakes and the area within the box designated as a plot (Figure 1).

\subsection{Monitoring Field Infection}

Beginning in late May or June, depending on wheat maturity that season, the 32 $1.22 \mathrm{~m}^{2}$ plots were hand harvested and each plot threshed using a Vogel small plot thresher (ALMACO, Nevada, IA). The total number of seeds per collected per plot was estimated by sample weight. Seed samples were shipped to USDA, APHIS, Olney, TX, where each was processed through an optical sorter [16] that was used routinely to screen USDA National Karnal bunt Survey samples. This device separated bunted or discolored kernels from the original sample, reducing the amount of kernels for examination from several kilograms to a few grams. Bunted kernels were hand counted using a vibrating grain table with a

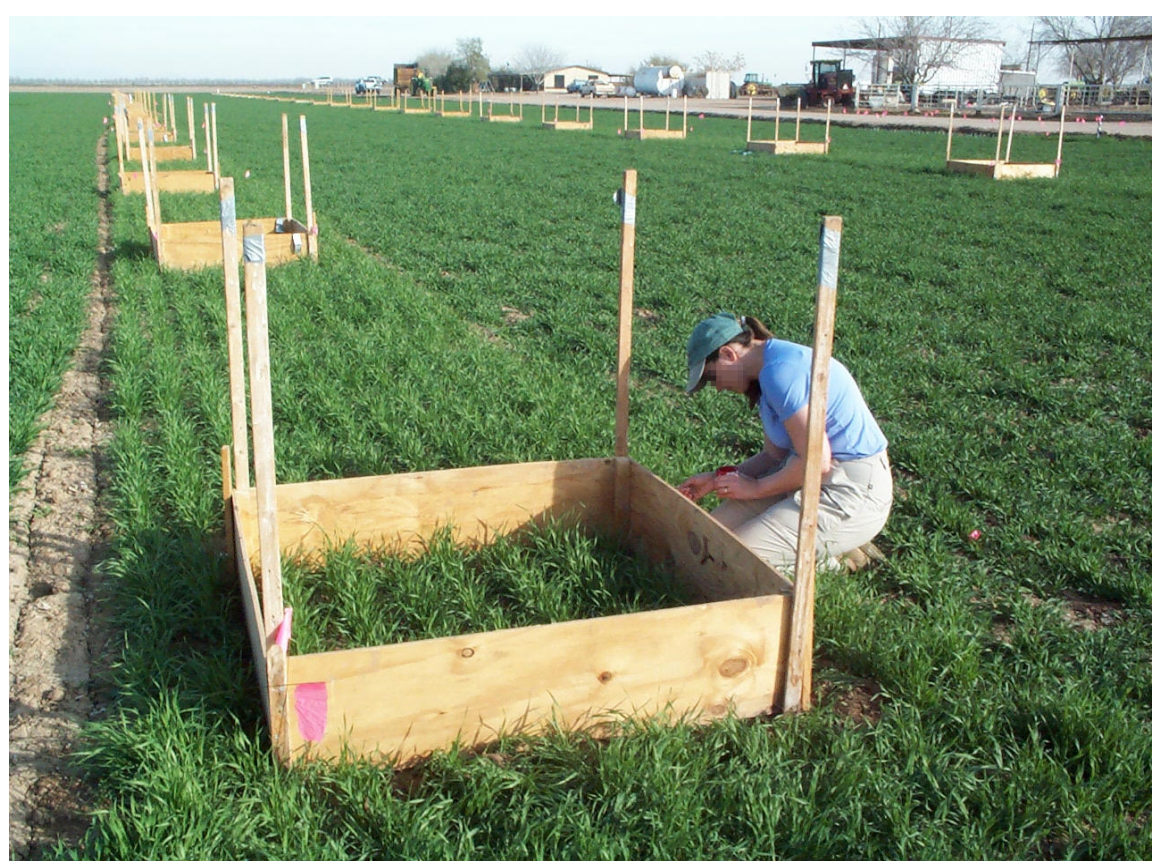

Figure 1. Rows of box-plots planted in parallel strips of wheat and the remainder of the field plated to barley. 
magnifier [17]. Data recorded were the percentage of bunted kernels per plot.

\subsection{Environmental Data}

Over the course of the study, hourly percent soil moisture (v/v) was measured at a depth of $5 \mathrm{~cm}$ with a ML2 ThetaProbe (Delta-T Devices, Ltd., Cambridge, UK) utilizing an Onset DL2 data logger (Onset Computer Corporation, Bourne, MA). Hourly soil temperatures at a depth of $5 \mathrm{~cm}$ were recorded using a HOBO Water Temperature Pro v2 Data Logger (Onset Computer Corporation, Bourne, MA). Air temperature and humidity were monitored hourly at $6 \mathrm{~cm}$ above the soil (sub-canopy) and one meter above the soil using a Hobo H08-032-IS (Onset Computer Corporation, Bourne, MA) or Watchdog A-Series (Spectrum Technologies, Aurora, IL) data loggers. Daily rainfall in millimeters was obtained from the University of Arizona AZMET weather station at the Maricopa Agricultural Center located $12.8 \mathrm{~km}$ southwest of the research plot. Upper canopy temperature and humidity data were used to calculate the Humid Thermal Index (HTI) for each season [18] [19] [20]. In Ludiana, India, Jhorar showed this model to be fairly reliable for predicting years when disease incidence will be high. The model is based on the average relative humidity at 2:30 PM from the time of boot emergence through anthesis divided by the average daily maximum temperature for the same time period. An HTI less than 2.2 would indicate dry, hot conditions whereas and HTI greater than 3.3 in indicated cold, moist conditions. An HTI between 2.2 and 3.3 is considered favorable for Karnal bunt development.

\subsection{Soil Sampling}

In 2002, prior to planting, 30 soil samples were collected in a zigzag pattern down the length of the field, $6-\mathrm{cm}$ deep, using a $0.92 \mathrm{~m} \times 2.54 \mathrm{~cm}$ dia. Hoffer soil sampler and samples composited. After Karnal bunt was observed in the field in 2004, sampling was conducted in a zig-zag pattern starting in the beginning of the first strip of wheat, crossing diagonally to the second parallel stripe of wheat, between the established $1.22 \mathrm{~m}^{2}$ plots, and then halfway between those two points in the barley. This pattern continued to the end of the field with a total of 25 points sampled. At each sampling point, three soil samples were taken from within in a $30 \mathrm{~cm}$ diameter circle with a Hoffer soil sampler, as described. The samples were divided into two; the top $0.5 \mathrm{~cm}$ of the three samples was removed with a spatula and composited together and the remaining $5.5 \mathrm{~cm}$ portion of the samples was also composited together. This was done to gain data on the teliospore population on the surface that has the potential to germinate and infect that season verses those below the surface that would be turned up to the surface next season during soil cultivation. Sampling was repeated several times during each growing season. In 2006 a duplicate set of samples were taken from a fallow wheat field approximately $300 \mathrm{~m}$ east of the experimental field for comparison with the teliospore population in the plots. 


\subsection{Quantitation of Teliospores and Viability}

Extractions were conducted in the USDA ARS FDWSRU BioSafety Level-3 plant disease containment facility at Fort Detrick, MD [21] under Federal and State permits. The composited soil samples collected in 2002 were subsampled 20 times, $25-\mathrm{cm}^{3}$ of soil per subsample, and extracted by a modified method of Rattan et al. [22] using a $25 \mathrm{~cm}^{3}$ sample volume. Each subsample was suspended in $20 \mathrm{ml}$ of Tween-20 water $(0.12 \%)$ in a $500 \mathrm{ml}$ beaker and mixed for 30 min with a $6 \mathrm{~cm}$ stir bar. The suspension was poured through a series of $600,250,100,53$ and $20-\mu \mathrm{m}$ pore size sieves and the debris trapped on a $20-\mu \mathrm{m}$ sieve, rinsed into a 50-ml conical centrifuge tube, centrifuged at $1,104 \times \mathrm{g}$ for 5 minutes, supernatant removed and debris pellet suspended in $1.0 \mathrm{ml}$ of Shear's mounting medium. Two hundred fifty $\mu \mathrm{l}$ of the suspension was transferred to a $1.5 \mathrm{ml} \mathrm{Ep}-$ pendorf tube and the entire volume examined for the presence of teliospores using multiple microscope slides with $22 \times 50$-mm coverslips. Slides were examined at 200X magnification to determine the number of teliospores per 250 $\mu l$.

Beginning in 2004, the extraction method was modified as described by Babadoost et al. [23]. Samples were air-dried in the lab and weighed. For each sampling point a 4 to $7 \mathrm{~g}$ sample from the top $0.5 \mathrm{~cm}$ deep soil composite and a10.0 g sample of the lower portion soil composite were extracted. Each composited $0.5 \mathrm{~cm}$ deep and $5.5 \mathrm{~cm}$ deep soil sample was transferred to a separate $50-\mathrm{ml}$ plastic screw-cap conical centrifuge tube and $35 \mathrm{ml}$ of Tween-20 water added. Samples were shaken and laid horizontally on an orbital shaker (190 rpm) for 15 min. Then, each sample suspension was passed through a 53- $\mu \mathrm{m}$-mesh sieve over a 2-1 beaker and the sieve contents washed with approximately $1.800 \mathrm{~L}$ of water delivered by a sprayer attached to a sink faucet. The filtrate was poured through a $20-\mu \mathrm{m}$-mesh sieve to trap the teliospores. The contents of each sieve was washed back into a 50-ml centrifuge tube and centrifuged for $3 \mathrm{~min}$ at $1,104 \times \mathrm{g}$. The supernatant was discarded the pellet suspended in $35 \mathrm{ml}$ of $1.6 \mathrm{M}$ sucrose solution. The suspension was centrifuged for $40 \mathrm{sec}$ at $206 \times \mathrm{g}$, and the supernatant poured into a $20-\mu \mathrm{m}$ pore size sieve and rinsed to remove the sugar. The centrifuge steps were also done three times with the soil pellet, each time pouring and rinsing the supernatant onto the same $20-\mu \mathrm{m}$ pore-size sieve. The sieve contents were rinsed into a new $50-\mathrm{ml}$ tube, the volume brought up to $35 \mathrm{ml}$, mixed, centrifuged for $5 \mathrm{~min}$ at $1,104 \times \mathrm{g}$, and the supernatant poured off. The pellet was suspended in $3.33 \mathrm{ml}$ of water, mixed well using a vortex mixer; 166.5 $\mu \mathrm{l}$ of suspension transferred to a $15-\mathrm{ml}$ tube and incubated at $18^{\circ} \mathrm{C}$ for $48 \mathrm{hrs}$ to hydrate or initiate germination of contaminants on the teliospore surface. The procedure results in determining the number of teliospores present in $5 \%$ of the subsample from the original field sample. The remaining suspension was centrifuged, supernatant poured off and pellet suspended in $3.16 \mathrm{ml}$ of Shears mounting medium. Two 33.3- $\mu$ d drops of this final dilution, representing $2 \%$ of the extracted sample, were transferred to two microscope slides and teliospores counted. 
After the $166.5 \mu \mathrm{l}$ sucrose fraction had been incubated for $48 \mathrm{hrs}$, it was suspended in $10 \mathrm{ml}$ of acidic electrolytic water and placed on a tube rocker for 30 $\mathrm{min}$ at $13 \mathrm{cycles} / \mathrm{min}$, centrifuged for $5 \mathrm{~min}$ at $913 \times \mathrm{g}$, supernatant poured off, and pellet re-suspended in sterile water. Two additional centrifuge washes were performed. After pouring off the supernatant, the pellet was re-suspended in 300 $\mu \mathrm{l}$ of sterile water. Twelve $10-\mu \mathrm{l}$ drops were aseptically transferred to each of a number of standard Petri dishes containing 2\% water agar amended with 100 $\mathrm{mg} / \mathrm{L}$ each of streptomycin sulfate and ampicillin. Dishes were incubated for 14 days and then examined for the percentage of teliospores that germinated.

\section{Results}

\subsection{Wheat Infection}

No bunted kernels were detected in the field for wheat harvested during 2003 and 2004. The first Karnal bunt detection in this field was in wheat planted in the fall of 2004 and harvested in 2005. Results for percentage of infected kernels for all field plots by year are presented in Table 1 .

\subsection{Environmental Data}

Soil moisture data for September through October 2005 and December 2006 are missing due to recorder malfunctions. The average monthly soil moisture and soil temperature data for each year are summarized in Figure 2 and Figure 3, respectively. Irrigation maintained the soil moisture in the range of 20 to $35 \%$ $(\mathrm{v} / \mathrm{v})$ during the wheat-growing season (December-May) in all years. There were no significant differences $(p=0.98)$ in monthly soil temperature averages between years. Total monthly rainfall is presented in Figure 4.

The HTI calculated from upper canopy air temperature and humidity each season was 1.82, 2.34, 2.08, 1.57 and 0.52 for 2003, 2004, 2005, 2006 and 2007, respectively. The only season that the HTI indicated was conducive to disease development was 2004 (HTI 2.34), which was the first year of the study where Karnal bunt was detected in the plots.

\subsection{Quantitation of Teliospores and Viability}

Soil sampling for detecting teliospores was begun after the 2004 infection in

Table 1. Average and range of Karnal bunt incidence detected in experimental plots by year.

\begin{tabular}{ccccc}
\hline Harvest Year & Average $^{1}$ & SD & MIN & MAX \\
\hline 2003 & 0.00 & 0.00 & 0.00 & 0.00 \\
2004 & 7.05 & 4.56 & 0.04 & 21.21 \\
2005 & 2.89 & 5.46 & 0.00 & 22.92 \\
2006 & 0.00 & 0.00 & 0.00 & 0.00 \\
2007 & 0.004 & 0.00 & 0.00 & 0.19 \\
\hline
\end{tabular}

${ }^{1}$ Percent infection. 


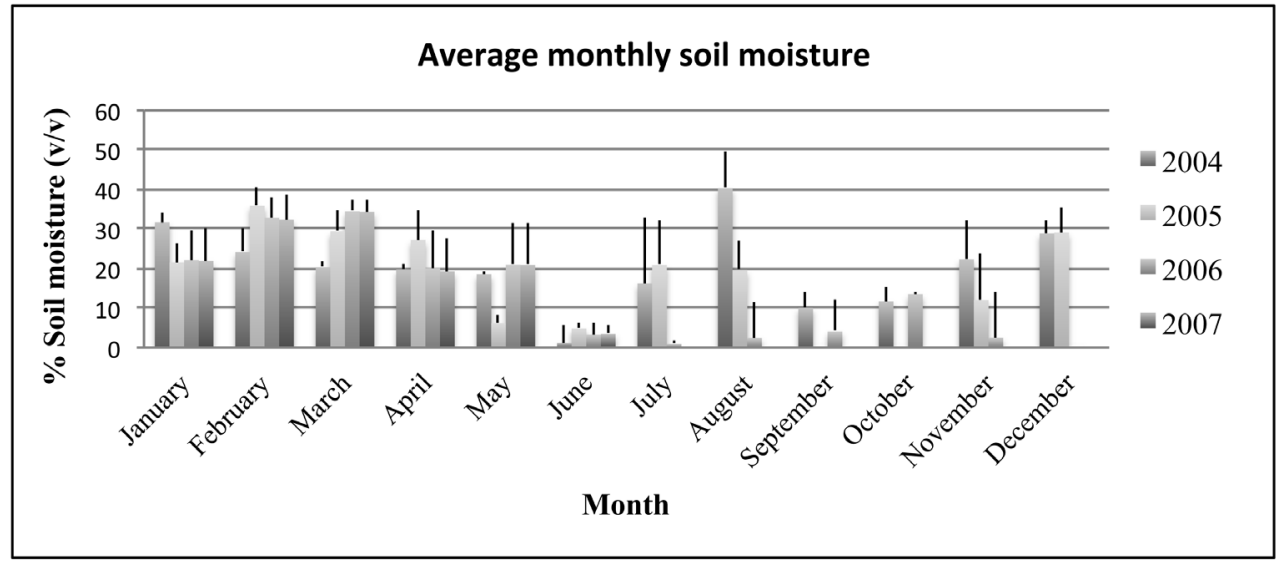

Figure 2. Average monthly percent soil moisture (SD) by year in the Tilletia indica research field at Maricopa, AZ.

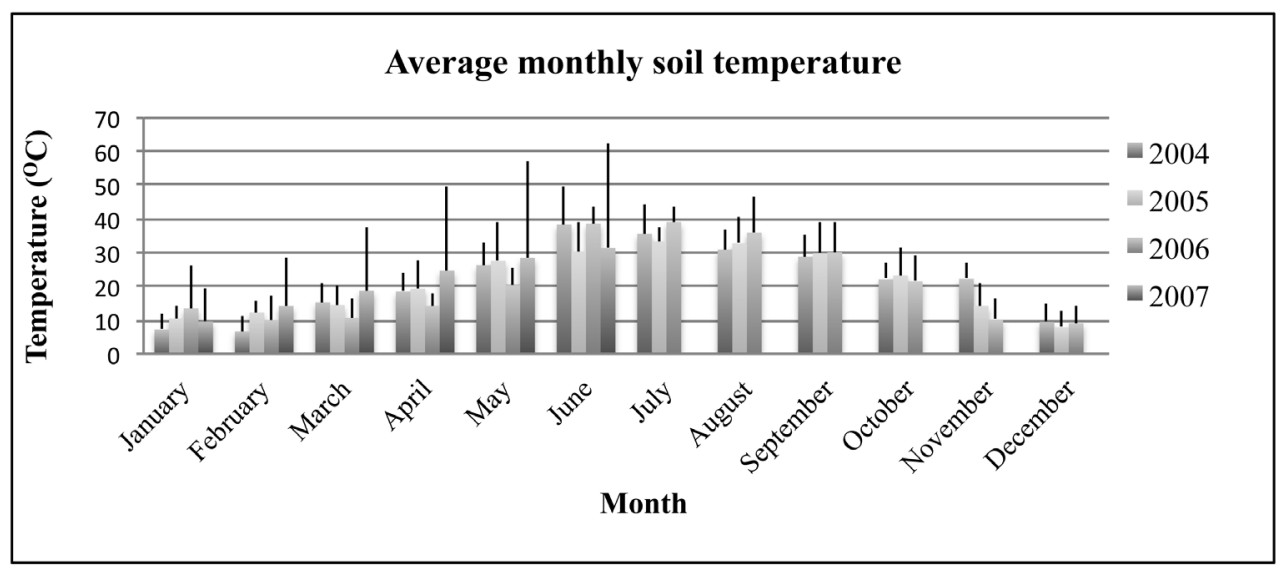

Figure 3. Average monthly soil temperature (SD) by year recorded $5 \mathrm{~cm}$ below the surface at the Tilletia indica research field at Maricopa, AZ.

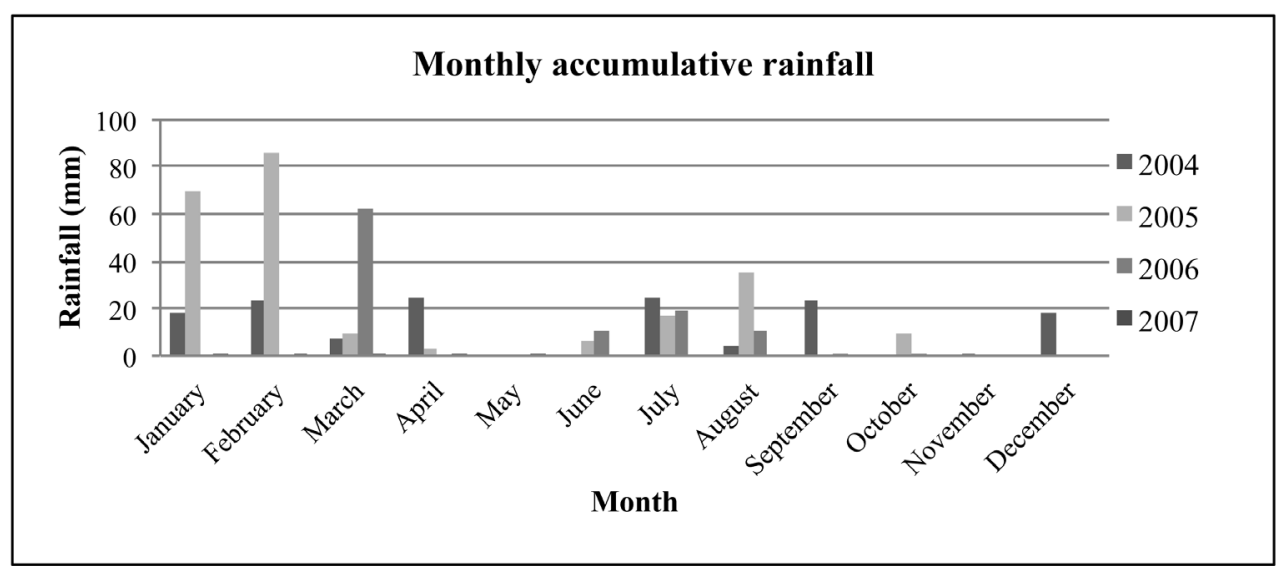

Figure 4. Accumulated monthly millimeters of rainfall for each year, 2004 though 2007 recorded at the nearby AZMET weather station in Maricopa, AZ.

January 2005. Results showing the average number of teliospores per gram of soil recovered at each sampling time, for the $0.5 \mathrm{~cm}$ deep of surface soil and the remaining $5.5 \mathrm{~cm}$ deep subsurface (Table 2). Data further are divided between 
soil samples taken in the areas of the field planted with wheat and those seeded in barley and the combined data of both. Analysis of variance found no significant differences $(p \leq 0.5)$ in the number of teliospores recovered from the soil planted to barley verses that seeded with wheat for any sampling time for either surface or subsurface soil. There was an average of $91.9 \%$ reduction in the number of teliospores recovered from the last natural infection occurrence in 2005 compared with the final sampling in 2007. No teliospores were recovered from soil collected in the field $300 \mathrm{~m}$ east of the experimental field (data not shown).

Table 3 presents the average number of teliospores per gram of soil that germinated by depth and crop for each sampling time. Analysis of variance found no significant differences $(p \leq 0.5)$ in the number of germinating teliospores from the different crop covers so data were combined for estimating the average number of germinating teliospores per gram of soil at the two depths for each sampling period and the estimated average percentage of the total population that germinated. From the July 2005 sampling in the infested field there was an average $90.2 \%$ decrease in germination of teliospores recovered in March of 2007. Regression analysis of time/teliospore recovery, and time/teliospore viability for each depth of sampling are shown in Figure 5. In all cases the coefficient of determination $\left(\mathrm{R}^{2}\right)$ suggested as trend toward a decrease in teliospore recovery and viability over time for each depth.

Table 2. Average number of extracted teliospores per gram of field soil.

\begin{tabular}{|c|c|c|c|c|c|c|c|c|c|}
\hline Crop & $\underline{\text { Depth }}$ & Łan 2005 & $\lcm{\mathrm{ul} 2005}$ & Nov 2005 & ఏan 2006 & Mar 2006 & Jan 2007 & Mar 2007 & Control Field $^{3}$ \\
\hline \multirow[t]{2}{*}{ Wheat } & Subsurface $^{1}$ & 40 & 36 & 10 & 8 & 6 & 5 & 2.5 & 0 \\
\hline & Surface ${ }^{2}$ & 32 & 88 & 21 & 6 & 13 & 4 & 6 & 0 \\
\hline \multirow[t]{2}{*}{ Barley } & Subsurface & 37 & 17 & 12 & 3 & 7 & 6 & 2.5 & 0 \\
\hline & Surface & 41 & 21 & 15 & 8 & 16 & 5 & 4 & 0 \\
\hline \multirow[t]{2}{*}{ Field Average } & Subsurface & 39 & 27 & 11 & 5 & 6 & 5.5 & 2.5 & 0 \\
\hline & Surface & 36 & 57 & 18 & 7 & 15 & 4.5 & 5 & 0 \\
\hline
\end{tabular}

${ }^{1} 0.5-6.0 \mathrm{~cm} ;{ }^{2} 0-0.5 \mathrm{~cm} ;{ }^{3}$ Soil samples collected from a field $300 \mathrm{~m}$ from the research field.

Table 3. Average number of germinating teliospores per gram of field soil and percentage of total spores germinating.

\begin{tabular}{cccccccccc}
\hline Crop & Depth & Jan 2005 & July 2005 & Nov 2005 & Jan 2006 & Mar 2006 & Jan 2007 & Mar 2007 $^{\text {Control Field }}$ \\
\hline \multirow{2}{*}{ Wheat } & Subsurface & 8 & 11 & 2 & 2 & 5 & 0 & 0.2 & 0 \\
& Surface $^{2}$ & 7 & 22 & 11 & 2 & 5 & 1 & 0.3 & 0 \\
Barley & Subsurface & 10 & 6 & 5 & 1 & 3 & 0 & 0.3 & 0 \\
& Surface & 7 & 3 & 7 & 2 & 8 & 0 & 0 & 0 \\
\multirow{2}{*}{ Field Average } & Subsurface & 9 & 8 & 4 & 2 & 4 & 0 & 0 & 0 \\
& Surface & 7 & 13 & 9 & 2 & 6 & 0 & 2 & 0 \\
Avg \% Germ. & Subsurface & 23 & 30 & 36 & 40 & 67 & 0 & 0 & 0 \\
& Surface & 19 & 23 & 50 & 29 & 40 & 0 & 2 & 0 \\
\hline
\end{tabular}

${ }^{1} 0.5-6.0 \mathrm{~cm} ;{ }^{2} 0-0.5 \mathrm{~cm} ;{ }^{3}$ Soil samples collected from a field $300 \mathrm{~m}$ from the research field. 


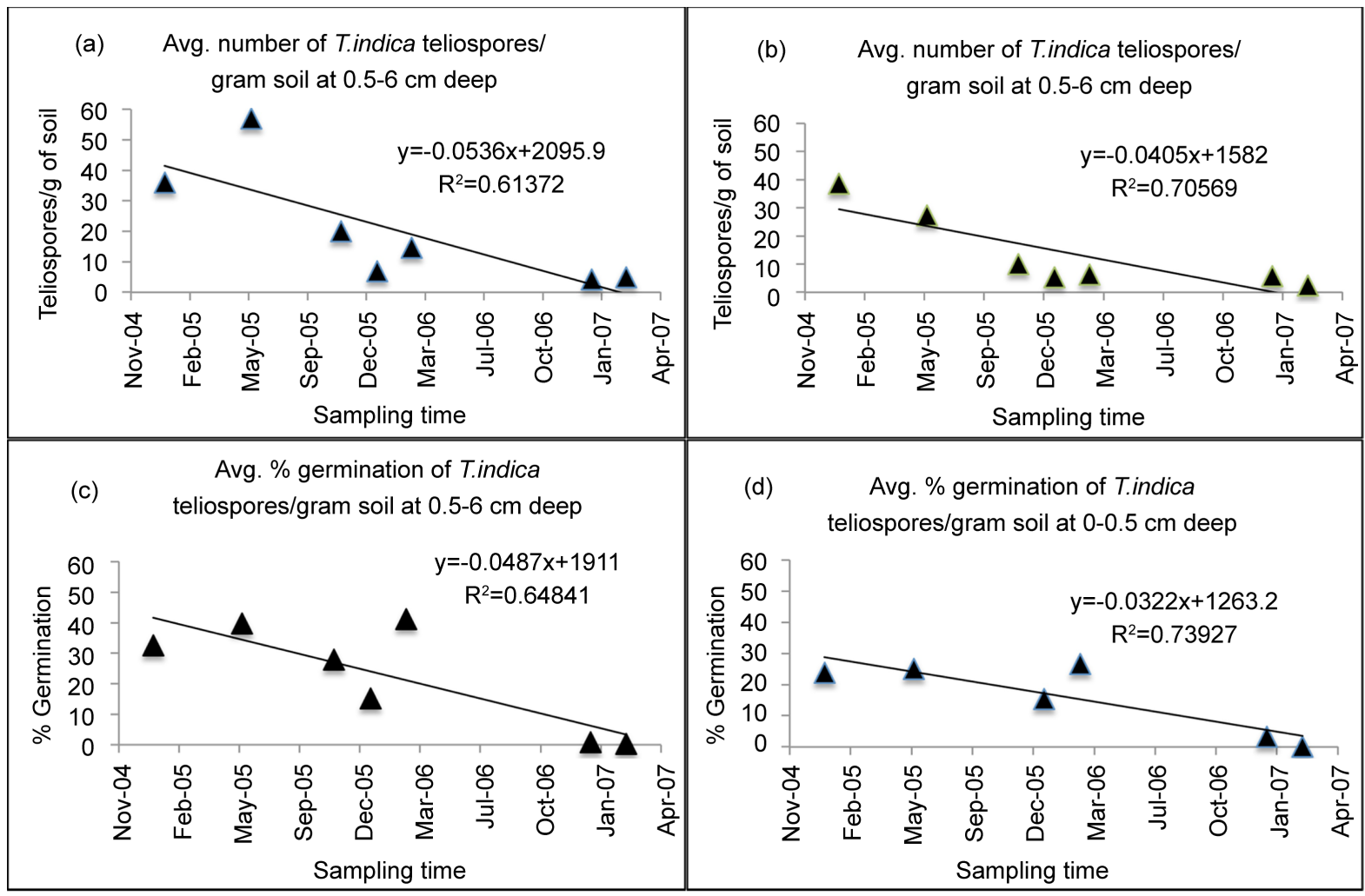

Figure 5. Regression analysis for time verses $T$. indica teliospores recovered from field soil at two depths (a,b) and time verses teliospore viability $(c, d)$.

\section{Discussion}

Wheat was grown and sampled in this field from 2002 through 2007 with measurable Karnal bunt occurring only in 2004 and 2005. No teliospores were detected in 2002 in composite soil samples processed by method of Rattan et al. [22] and no teliospores were detected by method of Peterson et al. [24] [25] [26] in three samples of remnant wheat seed planted in fall of 2003. The source of inoculum for the initial infection may have been an undetected residual that was not detected in earlier soil extraction of may have blown into the field from nearby infected fields. It is estimated in this region that an average of 0.08 $\mathrm{T} / \mathrm{ha} / \mathrm{yr}$ of soil moves by wind erosion and $7.60 \mathrm{~T} / \mathrm{ha} / \mathrm{yr}$ by water runoff [27].

No significant differences were observed in soil temperature between 2002 and 2007 that differentiated disease years from other non-disease years. Soil moisture during the growing season was fairly uniform across years because of controlled irrigation. In addition to data reported herein, hourly environmental data were collected for upper and lower canopy temperature and humidity throughout the study. When average maximum daily temperature recorded in the with the upper canopy and the mean daily relative humidity at 2:30 PM were used to calculate the Humid Thermal Index, model results for predicting favorable conditions for infection correctly identified 2004, our first and highest level in the study.

In earlier contained experiments, Bonde et al. [14] reported a decline in teliospore 
germination after 48 months of 76 and $92.9 \%$ in non-irrigated and irrigated fields, with no significant depth effect. Similarly, Babadoost et al. [13] reported an $85.2 \%$ decrease in recovery and $67.8 \%$ decrease in germination after 36 months with no depth effect. Rattan [12], working in Ludhiana, India, reported an $89.7 \%$ decrease in germination after 27 months with effect from soil-type or depth. In contrast, Inman et al. [15] reported no significant decrease in teliospore recovery or germination for samples buried in the UK and Italy for 36 months and no depth effect, however results for analyzing samples buried in Norway for 36 months noted a significant difference in recovery between years and a lower overall recovery than Italy and UK. Germination was significantly lower for 12 months versus 24 and 36 months. No depth effect was reported for the 36-month study. Inman suggested the recovery difference could be attributed to freezing and thawing of the soil and noted the soil type in both Norway and Italy were the same.

\section{Conclusions}

Results of this study conducted in a naturally infested field produced results most similar to those in the three controlled studies of Babadoost [13], Bonde [14] and Rattan [12]. In these studies there was a general trend of rapid decline in both the number of teliospores recovered and teliospore viability over the first 24 months. A small fraction of the population did remain viable beyond to scope of this study. It is possible that changes in teliospore numbers and viability could differ between artificially infested soil and natural field populations, however this study suggests that valid conclusions can be drawn from both artificially infected containerized soil and $T$. indica naturally infested soils. It is likely that the current disease management strategy of planting infested fields in a non-host crop or leaving them fallow while tilling the soil yearly for 60 months is an effective approach to disease management. In this study we planted wheat in the field each season, however not all years were conducive to disease development. $T$. indica was originally reported in limited locations in Southern California, Central Texas and Arizona in 1996 and 1997. After 2004, no reports of Karnal bunt have been reported in surveys in Texas and California likely due to the infrequent occurrence of favorable environmental conditions in these locations. Karnal bunt positive wheat fields in La Paz and Pinal County, Arizona continue to occur almost annually, with an additional 83 new fields in Pinal Co. noted in 2017 surveys. This would suggest a frequent reoccurrence of conductive conditions in some locations [28] [29]. Meanwhile, 1583 ha in Arizona have met the USDA criteria for deregulation and have been removed quarantine restrictions.

\section{Acknowledgements}

The authors would like to acknowledge the Support Scientist, Deborah GlennParish and Technician, Kathy Fronda, all formerly of USDA ARS FDWSR, Fort Detrick, MD and Theodore Boratynski, APHIS PPQ, El Centro, CA; We also 
express our gratitude to Loran Pratt and family; Joanne, Diane, David, Doug and Jacquie of Pratt Farms in Maricopa, AZ for use of land, research assistance and agronomic support. We appreciated the support of George Nash, APHIS PPQ, TX and the staff of the USDA-APHIS-PPQ National Karnal Bunt Sample Processing Laboratory is located in Olney, TX for use of their high-speed optical sorter.

\section{Endorsement Disclaimer}

The use of trade, firm, or corporation names in this publication (or page) is for the information and convenience of the reader. Such use does not constitute an official endorsement or approval by the United States Department of Agriculture or the Agricultural Research Service of any product or service to the exclusion of others that may be suitable.

\section{Equal Opportunity Statement}

The US Department of Agriculture (USDA) is an equal opportunity provider.

\section{References}

[1] Bonde, M.R, Peterson, G.L., Schaad, N.W. and Smilanick, J.L. (1997) Karnal Bunt of Wheat. Plant Disease, 81, 1370-1377. https://doi.org/10.1094/PDIS.1997.81.12.1370

[2] Ykema, R.E., Floyd, J.P., Palm, M.E. and Peterson, G.L. (1996) First report of Karnal bunt of wheat in the United States. Plant Disease, 80, 1207. https://doi.org/10.1094/PD-80-1207B

[3] Fuentes-Davila, G. (1998) Karnal Bunt of Wheat. In: Proceedings of Bunts and Smuts of Wheat: An International Symposium, North American Plant Protection Organization, Ottawa, 69-81.

[4] Da Luz, W.C., Mendes, M.A.S., Ferreira, M.A.S.V. and Urben, A.F. (1993) Tilletia indica on Wheat in the South of the State of Rio Grande do Sul, Brazil and Measures for Eradication. Fitopatologica Brasileira, 18, S329.

[5] Crous, P.W., Van Jaarsveld, A.B., Castlebury, L.A., Carris, L.M., Frederick, R.D. and Pretorius, Z.A. (2001) Karnal Bunt of Wheat Newly Reported from the African Continent. Plant Disease, 85, 561. https://doi.org/10.1094/PDIS.2001.85.5.561B

[6] Anonymous (2006) Karnal Bunt. Title 7 Code of Federal Regulations, Pt 301, ed., 123-139.

[7] Brennan, J.P. and Warham, E.J. (1989) Economic Losses from Karnal Bunt of Wheat in Mexico. Rpt. Joint CIMMYT-INIFAP Study, CIMMYT, Mexico.

[8] Brennan, J.P., Warham, E.J., Byerlee, D. and Hernandez-Estrada, J. (1992) Evaluating the Economic Impact of Quality-Reducing, Seed-Borne Diseases: Lessons from Karnal Bunt of Wheat. Agricultural Economics, 6, 345-352.

https://doi.org/10.1016/0169-5150(92)90010-V

[9] Sansford, C.E., Baker, R.H.A., Brennan, J.P., Ewert, F., Gioli, B., Inman, A., Kinsella, A., Magnus, H.A., Miglietta, F., Murray, G.M., Porta-Puglia, A., Porter, J.R., Rafoss, T., Riccioni, L. and Thorne, F. (2008) The New Pest Risk Analysis for Tilletia indica, the Cause of Karnal Bunt of Wheat, Continues to Support the Quarantine Status of the Pathogen in Europe. Plant Pathology, 57, 603-611.

[10] Regulated Areas (2005) Federal Register, 7 CFR Part 301.89-3(f). Vol. 70, No. 58. 
[11] Bonde, M.R., Berner, D.K., Nester, S.E., Peterson, G.L., Olsen, M.W., Cunfer, B.M. and Sim, T. (2004) Survival of Tilletia indica Teliospores in Different Soils. Plant Disease, 88, 316-324. https://doi.org/10.1094/PDIS.2004.88.4.316

[12] Rattan, G.S. and Aujla, S.S. (1990) Survival of Karnal-Bunt (Neovossia indica) Teliospores in Different Types of Soil at Different Depths. Indian Journal of Agricultural Science, 60, 616-618.

[13] Babadoost, M., Mathre, D.E., Johnson, R.H. and Bonde, M.R. (2004) Survival of Teliospores of Tilletia indica in Soil. Plant Disease, 88, 56-62. https://doi.org/10.1094/PDIS.2004.88.1.56

[14] Bonde, M.R., Nester, S.E., Olsen, M.W. and Berner, D.K. (2004) Survival of Teliospores of Tilletia indica in Arizona Field Soils. Plant Disease, 88, 804-810. https://doi.org/10.1094/PDIS.2004.88.8.804

[15] Inman, A., Magnus, H.A., Riccioni, L., Hughes, K., Coates, M., Barnes, A., Barton, V., Sansford, C., Valvassori, M., Di Giambattista, G., Porta-Puglia, A., Razzaghian, J. and Peterson, G. (2008) Survival of Tilletia indica Teliospores under European Soil Conditions. Plant Pathology, 57, 290-300. https://doi.org/10.1111/j.1365-3059.2007.01766.x

[16] Dowell, F.E., Boratynski, T.N., Ykema, R.E., Dowdy, A.K. and Staten, R.T. (2002) Use of Optical Sorting to Detect Wheat Kernels Infected with Tilletia indica. Plant Disease, 86, 1011-1013. https://doi.org/10.1094/PDIS.2002.86.9.1011

[17] United States Department of Agriculture, Animal and Plant Health Inspection Service (2007) Karnal Bunt Manual. USDA APHIS, 164 p.

http://www.aphis.usda.gov/import_export/plants/manuals/domestic/downloads/kb. pdf

[18] Jhorar, O.P., Mavi, H.S., Sharma, I., Mah, G.S., Mathauda, S.S. and Singh, G. (1992) A Biometeorological Model for Forecasting Karnal Bunt Disease of Wheat. Plant Disease Research, 7, 204-209.

[19] Stansbury, C.D. and McKirdy, S.J. (2001) Forecasting Climate Suitability for Karnal Bunt of Wheat: A Comparison of Two Meteorological Methods. Australasian Plant Pathology, 30, 1-12. https://doi.org/10.1071/AP00054

[20] Workneh, F., Allen, T.W., Nash, G.H., Narasimhan, B., Srinivasan, R. and Rush, C.M. (2008) Rainfall and Temperature Distinguish between Karnal Bunt Positive and Negative Years in Wheat Fields in Texas. Phytopathology, 98, 95-100. https://doi.org/10.1094/PHYTO-98-1-0095

[21] Melching, J.S., Bromfield, K.R. and Kingsolver, C.H. (1983) The Plant Pathogen Containment Facility at Frederick, Maryland. Plant Disease, 67, 717-722. https://doi.org/10.1094/PD-67-717

[22] Rattan, G.S., Aujla, S.S. and Sharma, I. (1989) Estimation of Teliospores of T. indica from Field Soil. Plant Disease, 73, 804. https://doi.org/10.1094/PD-73-0804

[23] Babadoost, M. and Mathre, D.E. (1998) A Method for Extraction and Enumeration of Teliospores of Tilletia indica, T. controversa and T. barclayana in Soil. Plant Disease, 82, 1357-1361. https://doi.org/10.1094/PDIS.1998.82.12.1357

[24] Peterson, G.L., Bonde, M.R. and Phillips, J.G. (2000) Size-Selective Sieving for Detecting Teliospores of Tilletia indica in Wheat Seed Samples. Plant Disease, 84, 999-1007. https://doi.org/10.1094/PDIS.2000.84.9.999

[25] Goates, B.J. and Peterson, G.L. (1999) Relationship between Soilborne and Seedborne Inoculum Density and the Incidence of Dwarf Bunt of Wheat. Plant Disease, 83, 819-824. https://doi.org/10.1094/PDIS.1999.83.9.819 
[26] Peterson, G.L., Kosta, K.L., Glenn, D.L. and Phillips, J.G. (2008) Utilization of Soil Solarization for Eliminating Viable Tilletia indica Teliospores from Arizona Wheat Fields. Plant Disease, 92, 1604-1610. https://doi.org/10.1094/PDIS-92-12-1604

[27] Zhang, Y.G., Nearing, M.A., Liu, B.Y., Van Pelt, R.S., Stone, J.J., Wei H. and Scott, R.L. (2011) Comparative Rates of Wind versus Water Erosion from a Small Semiarid Watershed in Southern Arizona, USA.

[28] United States Department of Agriculture, Animal and Plant Health Inspection Service (2015) National Karnal Bunt Survey. USDA APHIS, 164 p.

https://www.aphis.usda.gov/plant_health/plant_pest_info/kb/downloads/national-k b-survey.pdf

[29] APHIS Amends Karnal Bunt (Tilletia Indica (Mitra) Mundkur) Regulated Areas in La Paz, Maricopa, and Pinal Counties, Arizona, and Removes Silage from the List of Regulated Articles (2017) (CFR) 301.89-3(f). 